\title{
Dharma and the Indian Constitution
}

\author{
Leepakshi Rajpal* and Mayank Vats ${ }^{+}$
}

\section{Abstract}

\begin{abstract}
"Sarva Dharma Sambhavana" is a fundamental precept of Dharma. It is also the predominant thread that runs through several Supreme Court decisions. Was this merely coincidental, or does the Indian Constitution actually imbibe and mirror the principles of Dharma? The relation between Dharma and the Indian Constitution is examined keeping this very fundamental question in mind. The paper is an assertion that the Constitution is framed based on the principles of Dharma and not merely inspired by the western cultures, which the framers of the Constitution failed to realize. Dharma, as per popular notion, is not a singular construct of the Hindu way of life, but is common to all religions. Dharma and religion are two separate entities and are often confused to be one and the same. This paper clarifies these differences and through the descriptive and analytical method, traces the evolution of this concept and its subsequent connect with the laws that govern us. The crux of the paper lies in the fact that law and dharma are strongly interwoven and there is no way the two can be separated.
\end{abstract}

Keywords: Dharma, Indian Constitution, Life, Religion, Rights.

*Second year, BA LLB, Symbiosis Law School, Hyderabad; leepakshi_writerswit@yahoo.in

+Second year, BA LLB, Symbiosis Law School, Hyderabad; mailto_mayankvats@yahoo.in 


\section{Introduction}

Dharma, as a concept is less known and has had different meanings through different eras. It was considered as the order of the day during Ashoka's era and dictated all actions of the subject of the state; the dharma as preached by the Buddhists and Hindus and subsequently, a new era of Dharma emerged which was an excellent culmination of pre-existing concepts and principles.

\section{Dharma and Buddhism}

Buddhism was founded by a royal prince named Siddhartha Gautama, when he stepped out of his palace to realize a world of miseries, hitherto unknown to him. Subsequently, he retired and renounced the world and went into forests for spiritual meditation. After six years of immense spiritual meditation, he attained enlightenment under a tree named Bodhi in Bodh Gaya. He was directed to teach the universe and consequently, he rose from his meditation and taught the first wheel of Dharma. The teachings of Buddha mainly focused on Buddha's meditations and the concept and characteristics of Dharma. He began his first sermon in the Deer Park and began preaching by revolving the wheel with eight spokes which represented the noble Eight Fold Path. This was an indication of the fact that his teachings may go round and round but the center i.e. nirvana is always fixed.

The Eight fold path included the following teachings:

I. Right view - We should view everyone with the eyes of wisdom and compassion.

II. Right thought - What we think, is what we become. With clear and good thoughts we are likely to have a strong character.

III. Right speech - We should always speak kind and respectful words, by this we earn respect and trust.

IV. Right conduct - We should know how to behave courteously and not waste our time criticizing others, because even we can have some loopholes which others may criticize. 
V. Right livelihood - We should always choose a job that does not hurt others. Buddha said, "Do not earn your living by harming others".

VI. Right effort - We should always give our best in whatever we do and we should not harm others through our action and prefer such actions that are beneficial for those around us and for ourselves too.

VII. Right mindfulness - We should be aware of our thoughts, words and deeds. We should not possess any bad intention and should realize that good intention leads to good life.

VIII. Right concentration- We should focus on one thing at a time, this enables the mind to concentrate. ${ }^{1}$

During his enlightenment, Buddha found answers to three questions, which are considered to be the three great truths. The first truth he discovers is that nothing is lost in the universe, for instance, we are born out of our parents and our children are born out of us. Similarly, matter turns into energy and energy turns into matter. It means that everything in this universe is inter-connected and that the consequence of one's act could harm or benefit the other. It means that we all are inter-connected in such a way that even we fail to realize that such inter-connectivity exists. This is the reason why even law exists. In the modern day too, we are all interconnected in such a way, that the act done by one can harm or benefit the other. This is what even law does. If it benefits, it is good, but if it harms, law lays down the provisions for punishment. It also lays down the principles based on which our work should be done i.e. not the nature of the task or work but the actual basic generosity out of which the work should be carried out.

The second truth he unveiled is that everything changes. He said that life is like a river, it flows on and on, sometimes swiftly, sometimes slowly, but it still keeps going. In the modern day world too, nothing is constant and change is necessary, though it is difficult but eventually after the change, everything falls into place. Similarly, law has to be changed from time to time to meet the

\footnotetext{
${ }_{1}^{1}$ Ajaan Lee Dhammadharo, The Path to Peace and Freedom for the Mind (Dec. 1, 2013), http://www.accesstoinsight.org/lib/thai/lee/pathtopeace.html.
} 
needs of different population and different circumstances in which it falls. The third truth he discovered was the Law of cause and effect. This is also known as Law of Karma or the Karma theory. It simply states that what one gives is what one gets; there is nothing out of the boundary that one will be receiving or giving. It is best explained by the paragraph given in the Dhammapada:

The kind of seed sown

will produce that kind of fruit.

Those who do good will reap good results.

Those who do evil will reap evil results.

If you carefully plant a good seed, you will joyfully gather good fruit.

- Dhammapada ${ }^{2}$

\section{The Theory of Dharma as Taught by History}

Ashoka, the famous ruler from the Gupta Dynasty, was also known as the watershed figure in the history of Dharma ${ }^{3}$, because of the work he did during his reign such as the distinctive set of texts, inscriptions on the rocks and pillars and preaching of Dhamma, making him the originator of the concept. He termed his edicts Dhammalipi, which means to broadcast an imperial programme. ${ }^{4}$ The term was coined with some special connotation, albeit later, the brahmanas used it to promote their royal patronage. The inscriptions he wrote on the pillars and rocks were mainly found in two scripts i.e. Brahmi and Kharosthi, ${ }^{5}$ which conveyed"crude" Prakrit, that was perhaps Ashoka's own language. In one rock edict he wrote that as of his tenth year he would go on Dhammmayatas i.e. dhamma tours, giving audience in the provinces (janapadas), preachings on Dhamma and discussing questions about Dhamma i.e. dhammaparipuccha, deriving a "second revenue" in the form of

${ }^{2}$ San Fransico State University, Following the Buddha's Footsteps, (Dec. 8, 2016), http://online.sfsu.edu/rone/Buddhism/footsteps.htm.

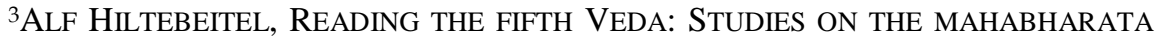
35 (Patrick Olivelle, Oxford University Press $1^{\text {st }}$ ed., 2011).

${ }^{4}$ N. A. Nikram, ET. AL. EDICTS ON Dharma 32 (Richard Mckeon et al eds., University of Chicago Press $1^{\text {st }}$ ed. 1978).

${ }^{5} I d$ at $15-16$. 
pleasure. ${ }^{6}$ He usually began his preaching of dhamma in an oral form and ended it by writing, perhaps to ensure that this concept does not remain unknown to the future generations.

An excerpt of a rock edict known as the Minor Rock Edict (MRE), written in his tenth year is presented below. It states that:

King Devanampiya speaks thus: For two and half years I was a Buddhist Layman and I was not very zealous. For somewhat more than a year I visited the Sangha and became very Zealous. The Gods have formerly not mingled with men, but now they are mingled. This is the result of zeal. Not only high persons can reach this aim, now, even common people can reach it if they are very zealous. ${ }^{7}$

Thus, evidently, Dhamma or Dharma is not only a game of the rich and wealthy, but even a common man can unite with the God, if he so believes and does all the righteous actions, zealously.

By his twelfth year as a ruler, he started promulgating Dhamma by "summoning people to the tableaus of celestial palaces, tableaus of elephants, balls of fire and other divine displays". 8 He tried to manipulate the images of divinity, similarly done by Kautilya in the Arthashastras. The methods used by him to preach the teachings of Dhamma, depict manipulation in the images of the Lord Buddha and the sources connected or related to him. This also indicates the gullibility of his populace for believing everything he said to be true and divine. He used this method of preaching because he learned that this would help him gain support and confidence of the people.

In total, there were seven pillar edicts preaching Dhamma by King Ashoka. In these seven pillars of inscriptions, he has reflected on the nature of Dharma, the control of sin and passion, celebration of feasts and animal slaughter, and even mentions the preacher of

6JULES BLOCH, LES INSCRIPTIONS D'ASOKA 112-113 (Les Belles Lettres $1^{\text {st }}$ ed. 1950).

${ }^{7}$ Harry FalK, ASOKAN SITES AND ARTEFACTS: A SOURCE-BoOK WiTH BIBLIOGRAPHY 77 (Philipp Von Zabern $1^{\text {st }}$ ed., 2006).

${ }^{8}$ Found in the Fourth Rock Edict (RE4). 
Dhamma. ${ }^{9}$ He was also of the view that Dhamma can be attained through deep meditations than by moral principles. Thus, it is evident that the preaching of Dhamma according to Ashoka was more motivated by his political and administrative interests, leading to a more general than imperial view of Dhamma.

Despite the criticisms, Ashoka saw Dhamma in a grand picture. He did this more in social terms than in matters of detail.Firstly, regarding the "ethical import" of his edicts, Ashoka's repeated injunction was to be respectful to each and every individual no matter what caste one belonged to. He also said that he paid respect to and had a respectful concern for the happiness of all groups and classes. Secondly, as observed by Nikam and McKeon, "Far from restricting Dharma to the tenets and practices of single religion, Ashoka asserts that Dharma is cultivated in all religions and sects and he seeks to advance Dharma in all the men and women whatever their religious affiliations. In fact, the Indian Constitution has adopted secularism from the concept of Dhamma or Dharma. Secularism means that the state respects all religion and does not adopt or give to itself any one religion. It is a neutral approach towards life, evidently in existence since the time of King Ashoka.

Thirdly, a generalized form of Dhamma, helped Ashoka to control his state and propagate himself into something big. He used this technique of preaching for gaining support. But this also resulted in the appointment of the "controllers" and the "provincial governor" 10 at different levels, showing the existence of an effective administration then and the concept of separation of powers now. During the regime of Ashoka, power was delegated to a few individuals, who worked as a team, which is the basis of the modern concept of Centre, State and Local level governments. Therefore, it can be said that the concept of separation of power was wide spread in his regime and is not a modern concept. Fourthly, in the battle of Kalinga, King Ashoka himself later admitted that he had caused misery, and killed those people who "did" Dharma. He said that those left were the sources of Dharma

${ }^{9}$ RomilathapAR, ASOKA AND THE DECline OF THE MAURYAS 173 (Oxford University Press, $1^{\text {st }}$ ed. 1997).

${ }^{10} \mathrm{BLOCH}$, supra note 6 at 165. 
and those included the father, son, neighbors, brother, friends, relatives etc. and that he would help them and never fight a war again. ${ }^{11}$ This implicitly shows that the concept of modern day rehab centers and reformation centers is an indirect result of this. This self-realization and transformation in the case of Ashoka, in modern times, is enforced on people in rehab centers who are made to act upon the principles of Dharma to solve the conflict. His writing states that "descriptions of lay morality scattered throughout the ancient anthologies of universal wisdom"12. Thus, it can be inferred that the principles of natural justice i.e. justice, equity and good conscience is not a recent development in the field of law and was evident during the rule of Ashoka.

\section{Dharma in the Vedic and Post Vedic Ages}

The 'Rishimunis' (saints) of ancient India identified fourfold objectives of life. These objectives bestowed us with the way of living our life, trying to make it easy and simple. The objectives were Dharma (duties and obligations), Artha (material well-being), Kaama (pleasure) and Moksha (liberation).

Dharma has been defined as the highest ideal of a human life. It is a Sanskrit noun derived from root "dhr" and in the literal sense, it means "something which sustains or upholds". Dharma's semantic equivalent is the Greek term 'Ethos'. ${ }^{13}$ Max Muller defines Dharma as an Indian version of natural law, since people of the ancient times used Dharma as a way of life, to regulate their behavior and govern themselves. It was over a time that Dharma was related to religion. Dharma in Sanskrit language manifests the legal language of natural law or morality, more prominently and broadly in terms of perceptibility than found in religion, which is presented in the narrowest way by narrowest minds. ${ }^{14}$ Hence, Dharma need not necessarily be related or considered as religion only. It is beyond

11NIKRAM, supra note 4 at 45.

${ }^{12}$ ETIENNE LAMOTTE, LE TRAITE DE LA GRANDEVERTU DE SAGASSE 228 (Louvain: InstitutOrientaliste $1^{\text {st }}$ ed. 1998).

13Joel P. Brereton, Dhárman in the Rigveda, 32 J.L.P. 449, 449-89 (2004).

${ }^{14}$ K.L. BHATIA, THE CONCEPT OF DHARMA: CORPUS JURIS A COMPARATIVE STUDY OF LAW AND Morality 05 (Deep \& Deep Publications 2010). 
that and includes upholding duties and propagating it over generations to come. The concept of Dharma is predominantly associated with its literal meaning i.e. righteousness. It means righteousness of a man's actions. Through a lay man's perspective, it means doing whatever is right and not doing whatever is wrong. It is substantially associated with ethics and morals. It cuts across many a dissimilitude such as legal, social, moral and religious..

The concept of dharma is not modern and dates back to the early Vedic period, around 1500 B.C. This was when Aryans seized India from the northwest and colonized the plains of Punjab. The Rig Veda, which consists of various hymns in praise of Gods, were probably composed around 1200-1000 BC. The whole concept was introduced into religion by including them in ceremonial customs which centered on various sacrifices. There are numerous variations in the interpretation of the Vedas in the form of Upanishads. Srutis and Smritis were recognized as Sanatana Dharma or the eternal law. Sruti i.e. the heard knowledge were considered to be the highest source of knowledge and contained narrations on almost everything ranging from military to politics to common people's life. Smriti is another interpretation of the Vedas. There are four sages called Smritikars who have propounded the Dharmasastras and they are Manu, Yagnavalkaya, Brihaspati and Narada.

Puranas, which are eighteen in number, are another source and contain information about the creation and dynasties of god, sages and kings and detailed description of yugas. All the sources are on the same footstep and no one has supremacy over the other. A verse from Brihadaranyaka Upanishad illustrates the idea which makes people adhere to the Dharma, which is "Punyovaipunyena Karmanabhavati, PapahPapeneti", meaning 'everyone becomes good by good deeds and bad by bad deeds'. In other words 'every one reaps what he sows' and Dharma defines what is good.

India is a land of various religions and beliefs. Many religions are evolving while retaining their separate identity. Some of these include Hinduism, Islam, Buddhism, Sikhism, Jainism, Christianity and Parsi. These generally comprise of various sects making religion even more diverse. Hinduism as a religion, for instance, is 
unique and is categorized into many divisions in itself, but it is still one religion i.e. Hinduism ${ }^{15}$. There are three Gods in Hinduism who are considered to be the supreme i.e. Brahma, Vishnu and Shiva, the creator, preserver and destructor of this planet Earth. Together, these gods are known as Trimurti which means "triple form". Lord Brahma, as the sacred texts mention, had a clear and known personality, but was usually troubled by religion, power and the diffusion of sacred knowledge. Consequently, he created and conserved the concept of Dharma, i.e. doing one's own social duties and obligations and created the Vedas which is depicted by his four heads. ${ }^{16}$. Brahma recited the Vedas to the 'rishimunis' who had intense knowledge and were wise enough to do the task.

In Hinduis, Dharma defines or rather prescribes the moral code for the universe and is a way of living, elevating to the position of law, and is a duty which governs all the reality. The performance of one's Dharma is the ultimate goal of life. One can be liberated from the cycle of birth and rebirth (samsara) by following the path of Dharma. Since in the ancient times, Dharma was considered to be the only source of law, i.e. the Dharmashastras or Dharmasutras. British considered Dharmashastras to be the Civil Code of Conduct in India and hence, believed that dharmic texts were the reason for the prevalence of the caste system in India. ${ }^{17}$

It is clearly reflected in both Hinduism and Buddhism that Dharma is a moral duty towards oneself and towards the society. However, in today's twenty - first century, it is still difficult to implement the eight fold path or the Hindu form of Dharma. In ancient India, Dharma was considered the highest of rights and embodied the idea of supremacy of law as even the King was subject to it.

In Ananthapindika $v$. Jeta ${ }^{18}$, a case between the prince and a citizen of his state, the ruling was passed in favor of the citizen. The prince

${ }^{15}$ MARY PAT Fisher, Living RELIGIONS 67 (Upper Saddle River: Pearson Education Inc., $8^{\text {th }}$ ed., 2011).

16 G.M. Bailey, Trifunctional Elements in the Mythology of the Hindu Trimūrti, 26 NUMEN 152, 152-163 (1979).

17Shantanu Rathore, Dharma (Hinduism), https://berkleycenter.georgetown.edu/essays/dharma-hinduism. (Last visited Dec. 8, 2016).

18 As reported in the VinayaPitaka. 
followed the orders of the court. Everyone including the king or royalty were subject to the supremacy of the Court and everyone was considered equal in the state. This permeates into the Indian Constitution, in Article 14, which provides for equality before law.

However, the earlier known concept of Dharma eventually faded with Mughal era. The Muslims started their own practices and religion among their people, changing the meaning and concept of Dharma overtime. It was believed that Bakhtiyr Khilji invaded the Nalanda university fort, resulting in the decline of Dharma. However, Islamic texts provide that education is the best way to attain wisdom, and it is said that Khilji was unaware that Nalanda was a university. During the rule of many Muslim rulers, the Quranic teachings acquired the highest position of reverence, and Dharma was given no consideration. Muslim rulers discriminated against the Hindus and showed favoritism towards their own religious sects. Additionally, the British rule too contributed to the decline of Dharma. When the British invaded India, Lord Macaulay rejected the ancient Indian political system,19 stating that it was completely based on the supremacy of the Brahmanas over the other castes and did not enthrall within itself the concept of Fundamental Rights. This is because he failed to realize that Dharma was the basis of the Indian society at that time. When British brought in reforms and made certain laws for India and its people, they did not take into consideration what was being followed and made their own laws of governance. Eventually, Indians became more comfortable in the culture and traditions followed by the British rather than their own. However, they were still not treated with respect and integrity, and were devoid of all their rights too. Indians coveted for the life, peace and comfort they used to live while following the unwritten Dharma code of law in practice, since the ancient times. Being suppressed socially, economically, and politically, the Indians retorted back initially in the form of Revolt of 1857 and later in the form of many Nationalist Movements like Satyagraha and the Civil Disobedience Movement.

${ }^{19}$ Shodhganga, Human Rights and the Indian Constitution, http://shodhganga.inflibnet.ac.in/bitstream/10603/102509/9/09_chapter\%2003.pdf .(Last visited Dec. 8, 2016). 
Gandhiji, clearly stated that he was not disobeying the British law to show disrespect, rather he was obeying the higher law of our being, which was Dharma. 20

The struggle for independence was a fight for personal and civil liberties, basic rights and needs. However after independence, Hindu law (dharma) was codified keeping in mind the changes that were taking place in the ideals, lifestyle and outlook of the people. It was felt that the concept of Dharma in the ancient times should be related to the present times and be modified in a way that suits the needs of the present situations and still has same effect as it had in earlier times. ${ }^{21}$ Thus, post-independence, the framing of the Constitution of India was on the basis of the supreme law i.e. Dharma, the rule of law.

Article 13 of the Indian Constitution is thus worded as "Laws inconsistent with or in derogation of the Fundamental Rights:

(1) All laws in force in the territory of India immediately before the commencement of this Constitution, in so far as they are inconsistent with the provisions of this Part, shall to the extent of such inconsistency be void

(2) The State shall not make any law which takes away or abridges the rights conferred by this Part and any law made in contravention of this clause shall, to the extent of the contravention be void."22

The above stated article clearly states that the laws which were already made before the existence of the Constitution and are presently inconsistent with the Fundamental Rights i.e. the part which is not in accordance with the provisions of the Fundamental Rights, are to such extent void. If the laws made after the inception of the Constitution, are not in accordance with the provisions of the Fundamental Rights, they will be expressly declared as void, as stated by the Clause (2) of the Article. However, framers of our constitution failed to analyze that it is an Indian concept not a western one. The meaning of Dharma incorporates supremacy of

${ }^{20}$ Shantanu Rathore, Supra note 17.

21Ambujam v. T.S. Ramaswamy, AIR 1973 Delhi 46, 8 (1972) DLT 292.

22INDIA CONST. art. 13. 
law and rule of law. Even the king was required to act according to Dharma. The rule of sovereignty belonged to Dharma, and not to the king. Thus, the concept of Dharma is not different from the modern day rule of law which states that all the authorities of the State are subordinate to the law of the land. The adherence to rule of law is considered good for the society, as was the case when Dharma was prevalent as well. The rule of law also prescribes the duties and obligations a citizen owes to his nation, and Dharma too provided the same, though it was uncodified and understood as part of daily routine and proper conduct.

The Preamble of the Indian Constitution clearly states that India is secular in nature, and does not adhere to any particular religion, nor does it have any religion of its own. State is above every religion and supreme duty i.e. Dharma is above the state. Dharma is often related to humanity, and since humanity is above all, Dharma is above all. Thus, being secular inherently means that by not following any religion, we follow the supreme authority i.e. Dharma. It means that India does not consider any one religion or for that matter does not allow religion to interfere in decision making in matters of the state. It also means that by not accepting any one religion as supreme and considering itself as secular, it promises to safeguard every religion that prevails in the country. According to the Supreme Court of India, the definition of secularism with respect to all the religions is "Sarva Dharma Sambhavana", which means that state has no religion and shall treat all the people of different religious groups equally.

Moreover, it is the concept of Dharma that resulted in laying down Part III of the Indian Constitution i.e. the Fundamental rights. Fundamental rights are those rights which are available to a person by birth, and cannot be taken away until death. They are available to each and every individual without any discrimination based on gender, religion, caste, race, or economic status. It is the outcome of Dharma, i.e. the highest duty of a person which involves treating everyone equally with peace and harmony so that the society remains at peace. Fundamental rights are the codified version of the rights that people enjoyed in the ancient times.

Right to Life and personal liberty is enshrined in Article 21 of the Indian Constitution which states that no person shall be deprived 
of his life and personal liberty except according to the procedure established by law. The Indian judiciary has widened the scope of this article by giving it a broad interpretation. Its ambit covers the right to live with human dignity and not mere animal existence, ${ }^{23}$ right to livelihood, ${ }^{24}$ right to free legal aid, ${ }^{25}$ right of dignity of a convict ${ }^{26}$ but does not include the right to die. ${ }^{27}$.

In the case of Maneka Gandhi v. Union of India28, Justice Bhagwati in the Special Bench for the Supreme Court observed that:

The expression 'personal liberty' in the Article 21 is of the wider amplitude and it covers a variety of rights, which go to constitute the personal liberty of the man and some of them have been raised to the status of the distinct fundamental rights and given additional protection under Article 19. No person can be deprives of his right to go abroad unless there is a law made by the State prescribing the procedure for so depriving him, and the deprivation is effected strictly in accordance with such procedure.

Article 21 covers within its ambit every aspect which dignifies a human life and Dharma encompasses these human rights. It should be noted however, that Dharma and religion are not same. Justice J.Hansaria in A.S. Narayana Deekshitulu v. State of Andhra Pradesh and Ors. ${ }^{29}$ stated:

Religion is enriched by visionary methodology and theology, whereas dharma blooms in the realm of direct experience. Religion contributes to the changing phases of a culture; dharma enhances the beauty of spirituality. Religion may inspire one to build a fragile, mortal home for GOD; Dharma helps one to recognize the immortal shrine in heart.

\footnotetext{
${ }^{23}$ Kharak Singh v. State of U.P., AIR 1963 SC 1295.

${ }^{24}$ Maneka Gandhi v. Union of India, AIR 1978 SC 597.

${ }^{25}$ HussainaraKhatoon v. State of Bihar, AIR 1979 SC 1369.

26Union of India v. Bhanudas, AIR 1978 SC 1027.

${ }^{27}$ Gian Kaur v. State of Punjab, AIR 1967 SC 1257.

${ }^{28}$ Maneka Gandhi v. Union of India, AIR 1978 SC 597.

${ }^{29}$ A.S. Narayana Deekshitulu v. State of Andhra Pradesh \&Ors., 1996 AIR 1765, JT 1996 (3) 482.
} 


\section{Conclusion}

Dharma and law may sometimes be in contrast but their roots remain the same. Dharma and religion are not the same, but it can be said that religion is born out of Dharma. Essentially, with the evolution of Dharma, people are following their own version of Dharma. The existing law today i.e. the Constitution and other legislations including judicial pronouncements have been inspired by Dharma. Thus it can be said that Dharma and law are related to each other and are closely interwoven. 